\title{
Effects of pig slurry application on the diversity and activity of soil biota in pasture areas
}

\author{
Diversidade e atividade da biota do solo na avaliação dos \\ efeitos da aplicação de dejetos de suínos em áreas de pastagem \\ Danni Maisa da Silva ${ }^{I}$ Rodrigo Josemar Seminoti Jacques ${ }^{\text {II }}$ \\ Diego Armando Amaro da Silva ${ }^{\text {III }}$ Natielo Almeida Santana ${ }^{\text {IV }}$ \\ Eduardo Vogelmann ${ }^{V}$ Daniel Pazzini Eckhardt ${ }^{\text {VI }}$ Zaida Inês Antoniolli ${ }^{I I}$
}

ABSTRACT

The successive application of pig slurry to pastures is a common practice in southern Brazil, serving as a method of waste disposal as well as an important alternative to chemical fertilization. Although there are economic benefits to the use of manure as fertilizer, it may be associated with environmental hazards and cause changes to composition and activity of soil fauna. This study aimed to study the effects of pig slurry on the soil biota of pastures. Composition and biological activity of pastures where manure was applied successively for 2 years (A2) and 14 years (A14) were evaluated, and native forest (NF) was analyzed as a reference area. Successive application of pig slurry to the soil changed its biological characteristics according to the time of implementation; influenced the composition and diversity of soil fauna, leading to an increase in the total number of individuals, especially springtails; and increased the activity of the soil biota, especially to a depth of $6 \mathrm{~cm}$.

Key words: organic fertilization, soil fauna, bait lamina.

RESUMO

O uso sucessivo de dejetos de suínos em áreas de pastagem tem sido uma prática comum na região sul do Brasil, tendo em vista a necessidade de deposição dos dejetos produzidos, além de ser uma importante alternativa à fertilização das pastagens. Embora existam beneficios econômicos do uso dos dejetos como fertilizante, estes podem estar associados a riscos ambientais e causar alterações na composição e atividade da fauna no solo. Este trabalho teve por objetivo estudar os efeitos da aplicação de dejetos de suínos em áreas de pastagem sobre a biota do solo. Foi analisada a composição e a atividade biológica de áreas com uso de dejetos há 2 anos (A2), há 14 anos (A14) e mata nativa $(M N)$, como área referência. $O$ uso sucessivo de dejetos de suínos no solo alterou as características biológicas do solo, de acordo com o seu tempo de aplicação; influenciou a composição e a diversidade da fauna edáfica, aumentando o número total de indivíduos, principalmente de colêmbolos, e aumentou a atividade da biota do solo, especialmente até os $6 \quad \mathrm{~cm}$ de profundidade.

Palavras-chave: adubação orgânica, fauna edáfica, lâmina bait.

\section{INTRODUCTION}

Pig farming is an important economic activity in Brazil, particularly in the southern region, where nearly $50 \%$ of the national herd (PRODUÇÃO DA PECUÁRIA MUNICIPAL, 2010) is concentrated, primarily in rural family units. These producers raise pigs in confinement systems, and many combine pig farming with dairy cattle farming. In this case, pig slurry is generally the main form of pasture fertilization, which may lead to the accumulation of chemical elements in the soil that are toxic to crops and edaphic biota, such as $\mathrm{Cu}$ and $\mathrm{Zn}$ (LOURENZI et al., 2014).

Soil fauna perform different and important functions in the transformations that take place in the edaphic environment, actively participating in

\footnotetext{
'Universidade Estadual do Rio Grande do Sul (UERGS), Unidade Três Passos, Rua Cipriano Barata, 47, 98600-000, Três Passos, RS, Brasil. E-mail: danni.maisa@bol.com.br. Corresponding author.

"Departamento de Solos, Centro de Ciências Rurais (CCR), Universidade Federal de Santa Maria (UFSM), Santa Maria, RS, Brasil.

"IIPrograma de Pós-graduação em Ciência do Solo, Universidade Federal de Lavras (UFLA), Lavras, MG, Brasil.

${ }^{\text {IV }}$ Programa de Pós-graduação em Ciência do Solo, Universidade Federal de Santa Maria (UFSM), Santa Maria, RS, Brasil.

vInstituto de Ciências Biológicas, Universidade Federal do Rio Grande (FURG), São Lourenço do Sul, RS, Brasil.

${ }^{\mathrm{VI}}$ Universidade Federal do Pampa (UNIPAMPA), Dom Pedrito, RS, Brasil.
} 
the chemical, physical, and biological processes of the soil (LAVELLE et al., 2006). Based on these important functions, which are directly related to the production capacity of the soil and to environmental preservation, the density and diversity of the meso and macro-organisms may be considered excellent indicators of soil quality (VASCONCELLOS et al., 2013). Communities of edaphic organisms are highly sensitive to management practices, and may be altered by various factors, as well as by the addition of heavy metals to the soil (ANTONIOLLI et al., 2013). Soil management practices can have negative effects on the diversity and abundance of edaphic organisms, and alterations in edaphic communities caused by management practices may be reflected in the reduction of soil quality when they result in lower diversity, quantity, and activity of edaphic organisms. However, if soil management practices positively alter edaphic communities, they may result in improved soil quality.

Since the sequential addition of pig slurry may contribute to the improvement or maintenance of some chemical (VEIGA et al., 2012) and physical characteristics of the soil (AGNE \& KLEIN, 2014) and increase the availability of food for the soil fauna owing to the addition of large quantities of organic compounds, an increase in the density of organisms in the soil is to be expected. Thus, with adequate management and dosage, pig slurry may contribute to increased soil quality, promoting ecological equilibrium by reusing agricultural waste without polluting the environment (ALVES, 2008). The aim of this paper was to study the effect of successive applications of pig slurry in pasture areas on the biological composition and activity of the soil.

\section{MATERIALS AND METHODS}

\section{Characterization of the study areas}

The study was carried out in the city of Três Passos, RS (53'56'W and $27^{\circ} 30^{\prime} \mathrm{S}$ ) on wavyrelief terrain at an average altitude of 413 meters; Cfa climate, with an average annual temperature of around $19^{\circ} \mathrm{C}$; and precipitation between 1,800 and $2,000 \mathrm{~mm}$, well-distributed throughout the year (SILVA et al., 2014). The soil was classified as Entisol. The areas analyzed were: A2-Ryegrass+Tifton pasture with successive pig slurry application for two years; A14-Ryegrass+Tifton pasture with successive pig slurry application for 14 years in a rotational grazing system with dairy cows; and NF-native forest as a control. Areas were delineated in a $3 \times 2$ factorial arrangement composed of three areas and two collection periods (August and November of 2012), with three repetitions. In the analysis of the bait lamina, the arrangement was trifactorial, $3 \times 2 \times 4$, with three treatments, two periods, four depths, and three repetitions. Areas with successive use of pig slurry received around $200 \mathrm{~m}^{3}$ of slurry ha ${ }^{1}$ year ${ }^{-1}$.

Chemical and physical soil analyses and methods of soil biota analysis

Sampling for soil chemical and physical analysis was carried out in August 2012. Soil was collected at depths of 0 to 10 and 10 to $25 \mathrm{~cm}$, and the results of the weighted average at both depths in the NF, $\mathrm{A} 2$, and A14 areas are presented in table 1. Biological analyses of the litter bags were performed in August 2012. Other biological analyses were conducted in August and November of 2012. To survey the meso and macrofauna epiedaphic diversity, nine capture traps were installed in each area, according to the PROVID method (ANTONIOLLI et al., 2006), and remained in the field for a period of four days.

To determine the diversity of hemiedaphic and euedaphic organisms, the TSBF method (Tropical Soil Biology and Fertility; ANDERSON \& INGRAN, 1993 ) was used. Monoliths of $25 \times 25 \times 25 \mathrm{~cm}$ were collected on the same days as the PROVID installations in the field. After collection, the organisms were classified using a stereomicroscope in the laboratory. To evaluate the activity of the epiedaphic fauna, three litter bags (WIEDER \& LANG, 1982) were used per repetition. These were made of nylon, with dimensions of $30 \times 20 \mathrm{~cm}$ and a mesh of $10 \times 8 \mathrm{~mm}$ to allow the entry of soil micro, meso, and macrofauna (PODGAISKI \& RODRIGUES, 2010). A green mass of ryegrass leaves equal to $10 \mathrm{~g}$ of dry mass was packaged in each litter bag. The litter bags remained on the soil for 21 days. They were then collected and dried in an oven at $60^{\circ} \mathrm{C}$ until reaching a constant weight in order to determine the remaining mass by the difference between the initial and final plant mass. To determine biological activity, a bait lamina test (KRATZ, 1998) was used. It remained in the soil for 40 days (ANDRÉ et al., 2009).

\section{Statistical data analysis}

The edaphic fauna was evaluated quantitatively by the density and the activity of edaphic organisms. The data obtained were then subjected to analysis of variance (ANOVA) and the averages compared by a Tukey test $(\mathrm{P}<0.05)$, using the GENES program. A qualitative analysis of the soil fauna was performed by determining the richness of the groups collected, the relative frequency, 
Table 1 - Chemical and physical characteristics of soils in native forest (NF) and Ryegrass+Tifton pastures with the successive use of pig slurry for 2 (A2) and 14 years (A14): weighted average of the depths from 0 to $25 \mathrm{~cm}$, Três Passos, RS, 2012.

\begin{tabular}{|c|c|c|c|}
\hline \multirow{2}{*}{ Physical-Chemical Characteristic/Area } & NF & $\mathrm{A} 2$ & A14 \\
\hline & \multicolumn{3}{|c|}{-----Weighted average of the depths from 0 to $25 \mathrm{~cm}---$} \\
\hline $\mathrm{pH} \mathrm{H} \mathrm{H}_{2} \mathrm{O}(1: 1)$ & 6.4 & 6.0 & 5.9 \\
\hline $\mathrm{Ca}^{2+}\left(\mathrm{cmol}_{\mathrm{c}} \mathrm{dm}^{-3}\right)$ & 18.7 & 13.1 & 12.0 \\
\hline $\mathrm{Mg}^{2+}\left(\mathrm{cmol}_{\mathrm{c}} \mathrm{dm}^{-3}\right)$ & 4.1 & 5.80 & 5.40 \\
\hline $\mathrm{OM}(\%)$ & 5.0 & 2.6 & 4.1 \\
\hline $\mathrm{P}\left(\mathrm{mg} \mathrm{dm} \mathrm{m}^{-3}\right)$ & 4.6 & 25.1 & 33.8 \\
\hline $\mathrm{K}\left(\mathrm{mg} \mathrm{dm}^{-3}\right)$ & 304.3 & 311.5 & 462.7 \\
\hline Total $\mathrm{Cu}\left(\mathrm{mg} \mathrm{dm}^{-3}\right)$ & 191.6 & 257.8 & 221.9 \\
\hline Total $\mathrm{Zn}\left(\mathrm{mg} \mathrm{dm}{ }^{-3}\right)$ & 106.9 & 105.6 & 122.1 \\
\hline Density $\left(\mathrm{g} \mathrm{cm}^{-3}\right)$ & 0.86 & 1.23 & 1.29 \\
\hline Macroporosity $\left(\mathrm{cm}^{3} \mathrm{~cm}^{-3}\right)$ & 0.32 & 0.18 & 0.17 \\
\hline Microporosity $\left(\mathrm{cm}^{3} \mathrm{~cm}^{-3}\right)$ & 0.28 & 0.43 & 0.41 \\
\hline
\end{tabular}

the Shannon's Diversity Index $(\mathrm{H})$, the Simpson's Dominance Index (Is), and the Pielou's Evenness Index (J), and obtides as using DivEs 2.0 software. Analysis of the relationships between the taxonomic groups of the edaphic fauna and the chemical and physical attributes of the soil in the different areas was performed using Principal Component Analysis (PCA) in SPSS 19.0.

\section{RESULTS AND DISCUSSION}

Composition of the epiedaphic fauna-PROVID method Eight hundred fifty-five edaphic organisms were collected (average number of individuals captured per trap) in area A14 during the first collection period (August 2012), using the PROVID method (Table 2). The density of edaphic organisms was significantly greater in area A14 than in A2 (average of 229 organisms per trap) and NF (average of 160 organisms per trap). This is related to the large number of Collembola (average of 615 organisms per trap) in area A14, which comprised $71.93 \%$ of the total average number of individuals collected during this period. Springtails are considered important indicators of the biological condition and quality of the soil, as they are sensitive to environmental changes and anthropic interventions (SANTORUFO et al., 2012). Epiedaphic organisms collected during the first period (August) comprised 17 taxonomic groups (Table 2) in the areas analyzed.

During the second collection period (November 2012), the total number of edaphic fauna collected by PROVID was 73.10\% lower than the first period. This is likely due to pluviometric precipitation of $363 \mathrm{~mm}$ in the 40 days preceding the collection in November, which may have harmed the edaphic communities. The average temperatures were also higher in general, and thus more favorable to soil organisms during that time (around $20^{\circ} \mathrm{C}$ ) than in the 40 days preceding the collection in August (around $13^{\circ} \mathrm{C}$ ) (INMET/ BDMEP, 2014). This may also explain the more uniform density of edaphic organisms during the second collection period and the total number of springtails collected by PROVID, which was $92.65 \%$ lower than that of the first collection.

The Hymenoptera showed the secondhighest density and the lowest variation between the collection periods. The greater average abundance of these organisms in area A2 during the second collection period may be associated with their ease of locomotion. Concerning the richness of the edaphic fauna, area A2 presented the lowest number of taxonomic groups during both collection periods, even though the differences relative to the other areas were small. A14 showed the highest richness in the first collection period, which may be a consequence of its higher soil fertility (ROVEDDER et al., 2009).

Although area A14 showed greater richness, it was significantly lower the number of organisms, particularly of springtails, hymenopterans, and dipterans, in the first collection period, reflecting its lower diversity index $(\mathrm{H})$ (Table 2). This situation also explains its higher Simpson's Dominance Index (Is) as well as its lower Pielou's Evenness Index (J). SILVA et al. (2014) reported similar results in a study on pig slurry in various management systems, reporting an increase in springtails at the highest dose of slurry evaluated $\left(80 \mathrm{~m}^{3} \mathrm{ha}^{-1}\right)$ in a no-tillage planting system. 
Table 2 - Average number of epiedaphic individuals ${ }^{1}$ per taxonomic group, density, richness, Shannon's Diversity Index (H), Pielou's Evenness Index (J), and Simpson's Dominance Index (Is), determined by the PROVID method during two collection periods (August and November) in areas of native forest (NF) and Ryegrass+Tifton pasture where pig slurry was successively applied for 2 (A2) and 14 years (A14), Três Passos, RS, 2012.

\begin{tabular}{|c|c|c|c|c|c|c|}
\hline \multirow{2}{*}{ Group/Area } & $\mathrm{NF}$ & A2 & A14 & NF & $\mathrm{A} 2$ & A14 \\
\hline & \multicolumn{6}{|c|}{ 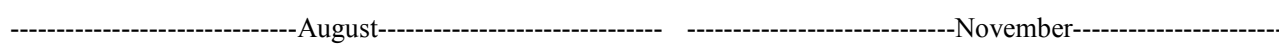 } \\
\hline Acari & 8 & 21 & 17 & 7 & 6 & 4 \\
\hline Annelida & 1 & 1 & 1 & 1 & 0 & 2 \\
\hline Arachnida & 4 & 6 & 11 & 5 & 8 & 11 \\
\hline Blattodea & 1 & 1 & 8 & 5 & 8 & 2 \\
\hline Chilopoda & 0 & 0 & 1 & 1 & 0 & 0 \\
\hline Coleoptera & 5 & 14 & 12 & 10 & 12 & 11 \\
\hline Collembola & 22 & 98 & 615 & 14 & 15 & 25 \\
\hline Dermaptera & 0 & 0 & 1 & 0 & 0 & 0 \\
\hline Diplopoda & 0 & 0 & 0 & 1 & 1 & 1 \\
\hline Diptera & 24 & 47 & 85 & 10 & 16 & 12 \\
\hline Hemiptera & 1 & 22 & 6 & 1 & 2 & 2 \\
\hline Hymenoptera & 79 & 16 & 89 & 25 & 53 & 35 \\
\hline Isopoda & 0 & 0 & 1 & 0 & 0 & 1 \\
\hline Isoptera & 13 & 2 & 5 & 11 & 6 & 4 \\
\hline Neuroptera & 0 & 0 & 0 & 0 & 0 & 1 \\
\hline Lepidoptera & 1 & 1 & 2 & 1 & 1 & 0 \\
\hline Orthoptera & 1 & 0 & 1 & 2 & 1 & 1 \\
\hline Total $^{2}$ & $160 \mathrm{~b}$ & $229 b$ & $855 \mathrm{a}$ & $94 \mathrm{a}$ & $129 \mathrm{a}$ & $112 \mathrm{a}$ \\
\hline Richness $^{3}$ & 12 & 11 & 15 & 14 & 12 & 13 \\
\hline $\mathrm{H}$ & 1.60 & 1.66 & 1.04 & 2.13 & 1.88 & 1.64 \\
\hline $\mathrm{J}$ & 0.64 & 0.69 & 0.38 & 0.81 & 0.76 & 0.74 \\
\hline Is & 0.30 & 0.26 & 0.54 & 0.15 & 0.22 & 0.19 \\
\hline
\end{tabular}

\footnotetext{
${ }^{1}$ Average of 9 repetitions per area.

${ }^{2}$ Total: Average number of individuals captured per trap.

${ }^{3}$ Total number of taxonomic groups found. Averages in each collection period followed by the same letter do not show a statistical difference in a Tukey's test at $\mathrm{P}<0.05$.
}

The PROVID results suggested that the successive addition of pig slurry to the soil contributed to the increase in the population of springtails. Although after 14 years of successive applications of pig slurry, the amount of copper in the soil exceeded the maximum concentration for investigation in agricultural soils, according to Resolution No. 420 (CONAMA, 2009), it was not sufficient to reduce the density of springtails in the soil. Conversely, the selection of more resistant populations and a reduction in the diversity of springtail species may have occurred. During the second collection period (November), an average of 94 individuals per trap were found in area NF, 129 were found in area A2, and 112 were found in area A14, distributed over 15 taxonomic groups. The native forest (NF) area showed the highest indexes due to a greater equilibrium in density between the taxonomic groups (Table 2).
Composition of hemiedaphic and euedaphic fauna TSBF method

Using the TSBF method, the total average densities of edaphic organisms found were 158 individuals per trap in area NF, 72 individuals per trap in area A2, and 296 individuals per trap in area A14 during the first collection period (August). These were, on average, higher than the numbers reported during the second period (November) (Table 3). An increase in the number of organisms with the successive application of pig slurry in the soil over time was also noted, since area A14 showed the highest density in both periods. The greatest number of organisms in both collection periods belonged to the order Hymenoptera, contributing to the low diversity indexes in area A14 during the first collection season. ALVES et al. (2008) reported that organic fertilization with pig slurry contributed to a greater frequency of Hymenoptera, Oligochaeta, and 
Table 3 - Average number of hemiedaphic and euedaphic ${ }^{1}$ individuals per taxonomic group, density, richness, Shannon's Diversity Index (H), Pielou's Evenness Index (J), and Simpson's Dominance Index (Is), determined by the TSBF method during two collection periods (August and November), in areas of native forest (NF) and Ryegrass+Tifton pasture with the successive use of pig slurry for 2 (A2) and 14 years (A14), Três Passos, RS, 2012.

\begin{tabular}{|c|c|c|c|c|c|c|}
\hline \multirow{2}{*}{ Group/Area } & NF & $\mathrm{A} 2$ & A14 & NF & $\mathrm{A} 2$ & A14 \\
\hline & \multicolumn{6}{|c|}{ 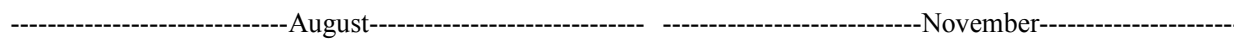 } \\
\hline Annelida & 12 & 29 & 35 & 3 & 2 & 80 \\
\hline Arachnida & 7 & 3 & 6 & 3 & 2 & 4 \\
\hline Blattodea & 1 & 0 & 0 & 1 & 1 & 1 \\
\hline Chilopoda & 10 & 4 & 4 & 5 & 1 & 4 \\
\hline Coleoptera & 2 & 7 & 9 & 3 & 3 & 10 \\
\hline Dermaptera & 2 & 0 & 1 & 1 & 1 & 2 \\
\hline Diplopoda & 0 & 0 & 1 & 1 & 0 & 1 \\
\hline Diptera & 2 & 2 & 11 & 1 & 1 & 14 \\
\hline Gastropoda & 15 & 0 & 0 & 8 & 0 & 0 \\
\hline Hemiptera & 1 & 4 & 1 & 1 & 0 & 2 \\
\hline Hymenoptera & 87 & 13 & 221 & 32 & 74 & 63 \\
\hline Isopoda & 2 & 1 & 3 & 1 & 1 & 1 \\
\hline Isoptera & 17 & 8 & 3 & 3 & 7 & 5 \\
\hline Lepidoptera & 0 & 0 & 0 & 1 & 0 & 0 \\
\hline Orthoptera & 0 & 1 & 1 & 1 & 3 & 1 \\
\hline Total $^{2}$ & $158 \mathrm{a}$ & $72 a$ & $296 a$ & $65 a$ & $96 a$ & $188 \mathrm{a}$ \\
\hline Richness $^{3}$ & 12 & 10 & 12 & 15 & 11 & 13 \\
\hline $\mathrm{H}$ & 1.59 & 1.81 & 0.99 & 1.79 & 0.98 & 1.54 \\
\hline $\mathrm{J}$ & 0.64 & 0.78 & 0.40 & 0.66 & 0.41 & 0.60 \\
\hline Is & 0.33 & 0.22 & 0.58 & 0.29 & 0.60 & 0.30 \\
\hline
\end{tabular}

${ }^{1}$ Average of 9 repetitions per area. ${ }^{2}$ Total: Average number of individuals captured per trap. ${ }^{3}$ Total number of taxonomic groups found. Averages in each collection period followed by the same letter did not show a statistical difference in a Tukey's test at $\mathrm{P}<0.05$.

Coleoptera, with their relative frequency dependent on the sampling period.

During the second collection period, Hymenoptera were also present at higher levels, but the greatest quantities were found in area A2. In the native forest, the highest richness and best diversity indexes were found in the second collection period. The highest density was found in area A14, with intermediate diversity, evenness, and dominance indexes in areas NF and A2 (Table 3).

Principal Component Analysis (PCA) of the edaphic fauna

The PCA separated the areas studied by two collection methods, PROVID and TSBF, and demonstrated that there is a relationship between the density and diversity of the edaphic fauna and the physical and chemical attributes of the soil. In the PROVID samples from the first collection period, two principal components accounted for $81.08 \%$ of the data variability. The first principal component (PC1) accounted for $54.24 \%$ of the data variability, and was composed of the following chemical variables, in order of importance: $\mathrm{H}+\mathrm{Al}, \mathrm{pH}, \mathrm{Mg}, \mathrm{Cu}$, and $\mathrm{Zn}$; physical variables: Density and Microporosity; and biological variables: Coleoptera, Diptera, and Collembola (Figure 1A). In the PCA of the data from the second collection period (November), two principal components (PC1 and PC2) accounted for $68.70 \%$ of the data variability, with $40.30 \%$ explained by $\mathrm{PC} 1$ and $28.40 \%$ by PC2 (Figure 1B). PC1 includes the following chemical variables, in order of importance: $\mathrm{H}+\mathrm{Al}, \mathrm{pH}, \mathrm{S}, \mathrm{Mg}, \mathrm{K}, \mathrm{Ca}$, in addition to $\mathrm{Cu}$ and $\mathrm{Zn}$; physical variables: microporosity, density, and macroporosity; and biological variables: Isoptera, Hemiptera, and Araneae.

In the data obtained by TSBF during the August collection, two principal components (PC1 and PC2) accounted for $81.92 \%$ of the data variability (Figure 1C). PC1 accounted for $55.0 \%$ of the variability, and was composed of the following chemical variables, in order of importance: P-Mehlich, \% OM, H+Al, pH, and $\mathrm{Cu}$; physical variables: Macroporosity, Density, 

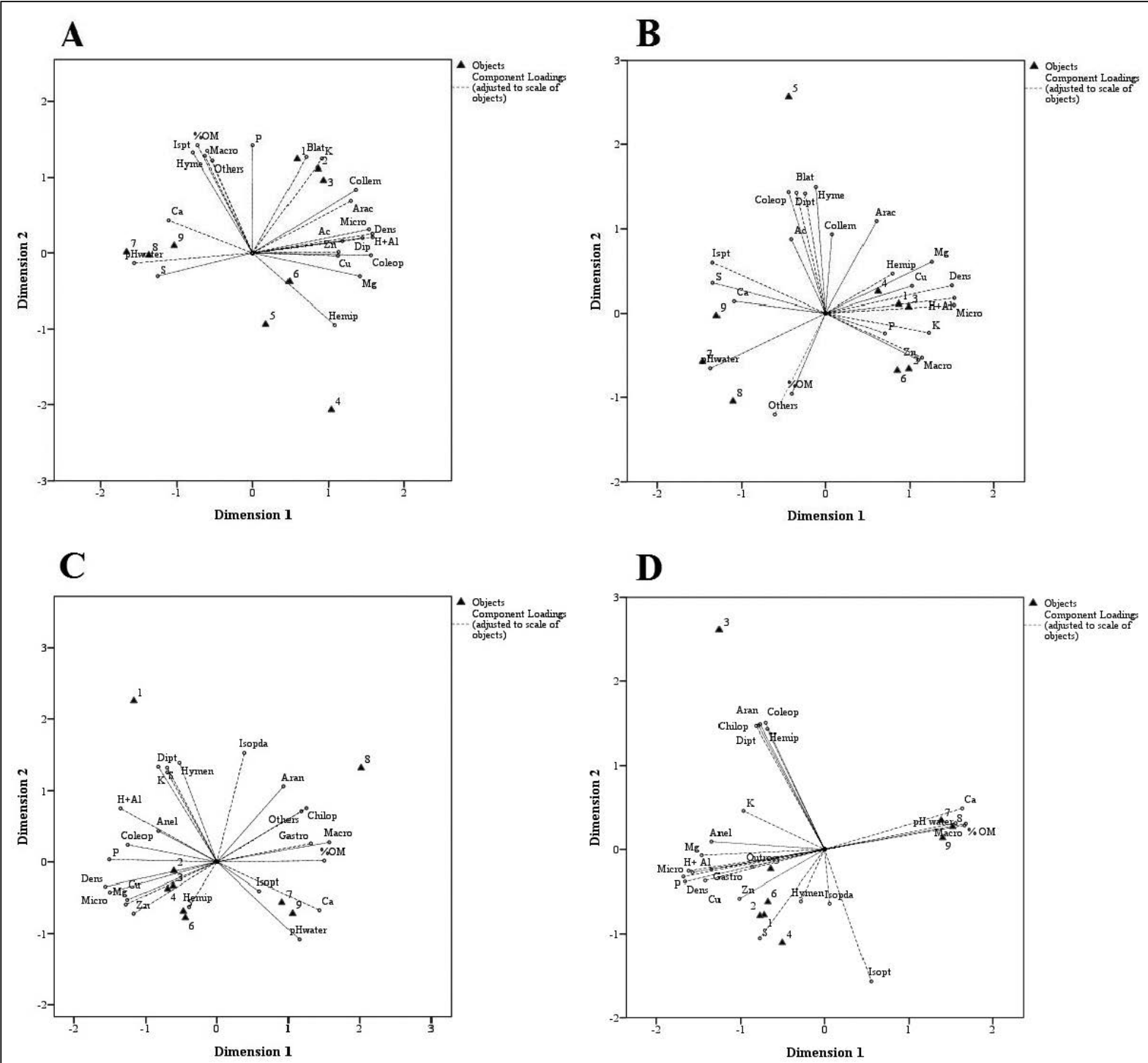

1,2, and 3, repetitions of A14 (Ryegrass+Tifton pasture area with successive use of pig slurry for 14 years); 4, 5, and 6, repetitions of A2 (Ryegrass+Tifton pasture area with successive use of pig slurry for 2 years); 7, 8, and 9, repetitions of NF (native forest); Dens (soil density), Micro (soil microporosity), Macro (soil macroporosity); Coleop (Coleoptera), Dip (Diptera), Collem (Collembola), Isopt (Isoptera); Hemip (Hemiptera), Anel (Annelida), Chilop (Chilopoda), Gastro (Gastropoda), Isopda (Isopoda), Arac or Aran (Araneae), Hyme or Hymen (Hymenoptera), Blat (Blattodea), Ac (Acarina).

Figure 1 - Biplot of the Principal Component Analysis (PCA) of the chemical, physical, and biological characteristics of soil with successive applications of pig slurry, using the data collected by PROVID (A and B) and TSBF (C and D) during collections in August (A and C) and November (B and D).

and Microporosity; and biological variables: Others, Coleoptera, and Araneae. In the PCA of the data from the second collection period (November), two principal components (PC1 and PC2) explained $78.9 \%$ of the data variability, with $53 \%$ explained by $\mathrm{PC} 1$ and $25.9 \%$ explained by PC2 (Figure 1D). In PC1, it was possible to infer that there was an interdependent relationship between these characteristics in soil and the use of pig slurry (Figure 1).
Evaluation of edaphic fauna activity using litter bags The analysis of litter bags showed a positive effect of the successive use of pig slurry in pasture areas on the process of waste decomposition by soil fauna. Reduction of the organic material packaged in the litter bags was 37,48 , and $43 \%$ for areas A2, A14, and NF, respectively, with no significant differences between the areas. This result may be associated with the greater density and diversity of edaphic organisms present in area A14 (Tables 2 and 3). 
The use of $10 \times 8 \mathrm{~mm}$ mesh may have permitted the entry of organisms from the macrofauna, but may also have led to a loss of material. Analysis of the mass of ryegrass plant material remaining in each litter bag showed variation from 3.99 to $9.23 \mathrm{~g}$ in one treatment, resulting in variability between the repetitions and the absence of statistical difference between areas. Thus, it is important that litter bag mesh should be as close as possible to the minimum size that allows the entry of macrofauna $(>2 \mathrm{~mm})$ in order to minimize the loss of plant material for the analysis.

Evaluation of edaphic fauna activity using bait lamina

An evaluation of soil fauna activity using bait lamina showed significant differences between periods and between the depths of soil analyzed (Table 4). During the first evaluation period (August), edaphic fauna activity was significantly higher than during the second period (November) at most of the depths analyzed (Table 4). These results appeared to be associated with the greater average density and diversity of fauna in the soil measured in August relative to November (Tables 2 and 3), which, in turn, seem to be related to precipitation. ANDRÉ et al. (2009) stress the sensitivity of the process of evaluating fauna activity through the use of bait lamina to environmental factors, which may determine the seasonality of the process of decomposition (KRATZ, 1998).
In our analysis of fauna activity in the soil at various depths, there was a significant difference beginning at $4 \mathrm{~cm}$ in the first collection period (August), and at $6 \mathrm{~cm}$ in the second collection period (November), with the highest activities registered up to these depths. Studies have indicated a higher average activity in the top $4 \mathrm{~cm}$ of the soil (ANDRÉ et al., 2009). The increased activity of the edaphic fauna in the top few centimeters of the soil is likely related to the improved physical and chemical conditions of the soil at these depths, and most activity was reported in areas with a higher concentration of organic matter in the soil (NF and A14) and appears to be related to the accumulation of organic material on the surface in NF; and in area A14, the result of successive applications of pig slurry. Although there were differences in food consumption between the study areas in the bait lamina assay, these were not statistically significant. In area A14, the activity of the edaphic organisms, in general, exceeded that in area A2.

Edaphic fauna are influenced by the addition of pig slurry, which affects the chemical parameters of the soil through its influence on nutrient content as well as physical parameters such as density and porosity. The meso and macrofauna of the soil are also influenced by edaphic factors, reflecting the conditions of the soil and the characteristics of the environment.

Table 4 - Average consumption of the substrate (\%) in bait lamina by edaphic fauna in Ryegrass+Tifton pasture areas with the successive use of pig slurry for 2 (A2) and 14 years (A14) and native forest (NF) during two collection periods (August and November), Três Passos, RS, 2012

\begin{tabular}{|c|c|c|c|}
\hline Depth $(\mathrm{cm})$ & Areas & August & November \\
\hline \multirow{3}{*}{$0-2$} & NF & $74.74 \mathrm{Aa}^{*}$ & $58.85 \mathrm{Aa}^{*}$ \\
\hline & $\mathrm{A} 2$ & 68.89 Aba & $49.22 \mathrm{ABb}$ \\
\hline & A14 & $68.49 \mathrm{Aba}$ & $59.38 \mathrm{Aa}$ \\
\hline \multirow{3}{*}{$2-4$} & NF & $66.66 \mathrm{ABCa}$ & $44.53 \mathrm{ABb}$ \\
\hline & A2 & 59.11 ABCDa & $39.84 \mathrm{ABb}$ \\
\hline & A14 & $58.61 \mathrm{ABCDa}$ & $39.32 \mathrm{ABb}$ \\
\hline \multirow{3}{*}{$4-6$} & NF & $52.60 \mathrm{BCDa}$ & $32.56 \mathrm{ABb}$ \\
\hline & $\mathrm{A} 2$ & 47.50 CDEa & $32.81 \mathrm{Aba}$ \\
\hline & A14 & 47.40 CDEa & $41.41 \mathrm{Aba}$ \\
\hline \multirow{3}{*}{$6-8$} & NF & $45.83 \mathrm{DEa}$ & $27.09 \mathrm{Bb}$ \\
\hline & $\mathrm{A} 2$ & $43.75 \mathrm{DEa}$ & $25.26 \mathrm{Bb}$ \\
\hline & A14 & $32.03 \mathrm{Ea}$ & $21.10 \mathrm{Ba}$ \\
\hline
\end{tabular}

*Averages followed by the same uppercase letter in the column (between depths) and lowercase letter in the row (between periods) do not show differences in a Tukey's test at $\mathrm{P}<5 \%$. 


\section{CONCLUSION}

The edaphic fauna was influenced by the successive applications of pig slurry to the soil, according to the length of its application period. Composition and diversity of the edaphic fauna were altered by the successive application of pig slurry, contributing to an increase in the total number of individuals, especially of springtails. Soil biota activity, analyzed using bait lamina, was influenced by the collection period of the analysis and by the depth of the soil, and was greater in the first $6 \mathrm{~cm}$ of soil.

\section{ACKNOWLEDGEMENTS}

The authors are grateful to the Conselho Nacional de Desenvolvimento Científico e Tecnológico (CNPq) for financial support of this study (Processes numbers 400420/2013-9 and 444165/2014-2).

\section{REFERENCES}

AGNE, S.A.A.; KLEIN, V.A. Organic matter and physical attributes of an Oxisol after swine waste application in perennial pastures. $\mathbf{R}$ Bras Eng Agríc Ambiental, v.18, n.7, p.720-726, 2014. Available from: <http://dx.doi.org/10.1590/S1415-43662014000700008>. Accessed: Oct. 18, 2014. doi: 10.1590/S1415-43662014000700008.

ALVES, M.V. et al. Soil macrofauna as influenced by chemical fertilizers and swine manure use in western Santa Catarina State, Brazil. R Bras Ci Solo, v.32, p.589-598, 2008. Available from $<$ http://www.redalyc.org/articulo.oa?id=180214228014 $>$.Accessed: Nov. 26, 2014. doi: 10.1590/S0100-06832008000200014.

ANDERSON, J.M.; INGRAM, J.S.I. Tropical soil biological and fertility: a handbook of methods. 2.ed. Wallingford: C.A.B. International, 1993. 171p.

ANDRÉ, A. et al. Bait-lamina assay as a tool to assess the effects of metal contamination in the feeding activity of soil invertebrates within a uranium mine area. Environ Pollution, v.157, p.23682377, 2009. Available from: <http://www.sciencedirect.com/ science/article/pii/S0269749109001481>. Accessed: Nov. 03, 2014. doi: 10.1016/j.envpol.2009.03.023.

ANTONIOLLI, Z.I. et al. Alternative method to study soil edaphic fauna. Ci Fl, v.16, n.4, p.407-417, 2006. Available from: <http:// coral.ufsm.br/cienciaflorestal/artigos/v16n4/A6V16N4.pdf>. Accessed: Jun. 10, 2012. ISSN 1980-5098.

ANTONIOLLI, Z.I. et al. Heavy metal, pesticides and fuels: effect in the population of collembola in the soil. Ciência Rural, v.43, n.6, p.992-998, 2013. Available from: $<$ http://dx.doi.org/10.1590/ S0103-84782013005000056>. Accessed: Sept. 18, 2014. doi: 10.1590/S0103-84782013005000056.

CONAMA (CONSELHO NACIONAL DO MEIO AMBIENTE). Resolução $n^{\circ}$ 420, de 28 de dezembro de 2009. Dispõe sobre critérios e valores orientadores de qualidade do solo quanto à presença de substâncias químicas e estabelece diretrizes para o gerenciamento ambiental de áreas contaminadas por essas substâncias em decorrência de atividades antrópicas.
Available from: <http://www.mma.gov.br/port/conama/legiabre. cfm?codlegi $=620>$. Accessed: Mar. 10, 2011.

INMET/BDMEP(INSTITUTONACIONALDEMETEOROLOGIA/ BANCO DE DADOS METEOROLÓGICOS PARA ENSINO E PESQUISA). Available from: $<$ http://www.inmet.gov.br/portal/index. php?r=bdmep/bdmep>. Accessed: Nov. 25, 2014.

KRATZ, W. The bait-lamina test. General aspects, applications and perspectives. ESPR. Environ Sci \& Pollut Res, v.5, n.2, p.94-96, 1998. Available from: <http://www.ncbi.nlm.nih.gov/pubmed/19005818>. Accessed: July 12, 2012. doi:10.1007/BF02986394.

LAVELLE, P. et al. Soil invertebrates and ecosystem services. Eur J Soil Biol, v.42, p.3-15, 2006. Available from: <http://www. sciencedirect.com/science/article/pii/S1164556306001038>. Accessed: Nov. 30, 2012. doi: 10.1016/j.ejsobi.2006.10.002.

LOURENZI, C.R. et al. Pig slurry and nutrient accumulation and dry matter and grain yield in various crops. R Bras Ci Solo, v.38, p.949-958, 2014. Available from: <http://dx.doi.org/10.1590/S0100-06832014000300027>. Accessed: Oct. 15, 2014. doi: 10.1590/S0100-06832014000300027.

PODGAISKI, L.R.; RODRIGUES, G.G. Leaf-litter decomposition of pioneer plants and detritivore macrofaunal assemblages on coal ash disposals in Southern Brazil. Eur J Soil Biol, v.46, p.394-400, 2010. Available from: <http://www.sciencedirect.com/science/ article/pii/S1164556310000713>. Accessed: Dec. 02, 2014. doi: 10.1016/j.ejsobi.2010.09.001.

PRODUÇÃO DA PECUÁRIA MUNICIPAL. Rio de Janeiro: IBGE, 2010. V.38, 65p. Available from: <http://www.ibge.gov.br/home/ estatistica/economia/ppm/2010/ppm2010.pdf>. Accessed: Oct. 07, 2014.

ROVEDDER, A.P.M. et al. Edaphic organisms as bioindicators of restoration of degraded soils by arenização on the Bioma Pampa. Cienc Rural, v.39, n.4, p.1061-1068, 2009. Available from: <http:// dx.doi.org/10.1590/S0103-84782009005000023>. Accessed: Dec. 02, 2014. doi: 10.1590/S0103-84782009005000023.

SANTORUFO, L. et al. Soil invertebrates as bioindicators of urban soil quality. Environ Pollution, v.161, p.57-63, 2012. Available from: $<$ http:// www.sciencedirect.com/science/article/pii/S0269749111005719>. Accessed: Dec. 02, 2014. doi: 10.1016/j.envpol.2011.09.042.

SILVA, R.F. et al. Doses of liquid swine slurry on soil biota community under no tillage and minimum tillage. Ciência Rural, v.44, n.3, p.418-424, 2014. Available from: <http://dx.doi. org/10.1590/S0103-84782014000300006>. Accessed: Oct. 07, 2010. doi: 10.1590/S0103-84782014000300006.

VASCONCELLOS, R.L.F. et al. Soil macrofauna as an indicator of soil quality in an undisturbed riparian forest and recovering sites of different ages. Eur J Soil Biol, v.58, p.105-112, 2013. Available from: <http:// www.sciencedirect.com/science/article/pii/S1164556313000642>. Accessed: Dec. 02, 2014. doi: 10.1016/j.ejsobi.2013.07.001.

VEIGA, M. et al. Chemical attributes of a Hapludox soil after nine years of pig slurry application. Pesq agropec bras, v.47, n.12, p.1766-1773, 2012. Available from: <http://dx.doi.org/10.1590/ S0100-204X2012001200013>. Accessed: Oct. 07, 2014. doi: 10.1590/S0100-204X2012001200013.

WIEDER, R.K.; LANG, G.E. A critique of the analytical methods used in examining decomposition data obtained from "litter bags". Ecology, v.63, p.1636-1642, 1982. 